\title{
European Tax Models
}

\author{
Narcisa Roxana Mosteanu, Mihaela Mitroi \\ Bucharest University of Economics Studies, Bucharest, Romania
}

\begin{abstract}
The research paper European Tax Models is a comparative analysis of the taxation systems in the European Union member states, taking into account the main features in light of the contribution of indirect and direct taxes and social contributions to the achievement of public revenues. Theme presents a topic of great interest, both theoretically and practically, given that how to place taxes has direct repercussions on the economic development of a country, and undoubtedly influence the rules of an economy, particularly in terms of investment, labor market, and social welfare. It was considered necessary in the first part of the paper to address the conceptual elements and present the most important features of tax systems and the principles that underlie them. It was studied from a theoretical perspective and it found the European tax models as follow: Nordic, continental, Anglo-Saxon, Mediterranean, and catching-up. Then, it analyzed each fiscal European model on each member country, starting from its economic indicators, based on Eurostat data. The objective of the research paper was to present a complete picture of the structure and trends of tax level of the member states of the European Union, sorted by European tax models and the impact of taxation on economic growth and social welfare. The research has concluded that, as long as the rules of the European Union, member states are free to choose their own tax system along with their fiscal policy for economic development and having in a view of their geographical, historical, and political situation.
\end{abstract}

Keywords: European tax model, direct taxes, indirect taxes, fiscal revenue, implicit rate of consumption, individual tax burden, welfare index, unemployment rate, public debt, deficit, economic growth

\section{Introduction}

Taxation is an important source of revenue for any state budget. Over time, each state has tried to develop an optimal tax system, taking account of the socio-economic, political, geographical, historical, and etc.. The research has found that there are two approaches to the concept of the tax system. A first approach to the tax system is the sum of taxes from individuals and businesses that feed public budgets. The second approach is more complex, trying to bring together elements of economic, technical, and administrative work related to taxation. In this approach, the tax system consists of set of concepts, principles, processes, and methods related to tax items. Thus, this approach takes into account several elements such as event, matter taxable allowances, and tax subjects. Among these elements is manifested interdependent arising from the design, enactment, settlement, and tax collection. Tax items are managed under the tax laws of each state, in order to achieve the overarching objectives: economic development balanced state. This research found that each member state of the European Union freely determines its own tax system, as long as it respects the basic rules of the European

Narcisa Roxana Mosteanu, Ph.D., professor at Bucharest University of Economics Studies, Bucharest, Romania.

Mihaela Mitroi, Ph.D. student, Bucharest University of Economics Studies, Bucharest, Romania.

Correspondence concerning this article should be addressed to Narcisa Roxana Mosteanu, Finance Department, Romanian Academy of Economics Studies, University of Economics Studies, Bucharest, Romania. E-mail: narcisamosteanu@yahoo.com. 
Union (Retrieved from http://ec.europa.eu/taxation_customs/resources/documents/taxation/company_ tax/common_tax_base/cctbwp1finalrev1_en.pdf).

The basic concepts used in taxation refer to the setting, monitoring, and collection of taxes and other public financial resources, most participating in the formation of budget revenues. Ensuring the proper functioning of the tax system and tax regulations application requires a fiscal mechanism (Smith, 1776a). Tax mechanism through institutions and experts in the field helps to implement fiscal policy objectives and monitors the smooth running of the entire financial mechanism. The fiscal system is in place and set in motion by fiscal policy. Analysis undertaken noted that in most countries, fiscal objectives are through taxes, fees, contributions, namely through changes to their way of settlement, public expenditure, and control of budget deficit and the size of public debt.

According to economist Smith (1776b) and Musgrave (1990), usually, using resources from tax includes one horizontal equity rule requiring equal treatment of equal individuals and one of vertical equity which emphasizes proper differentiation among unequal individuals. Horizontal equity offers protection against arbitrary discrimination and also reflects the basic principles of equal value. ${ }^{1}$

The research undertaken by the new European Union member countries showed that there was no prefect system of taxation. Starting from the basic principles defined by Musgrave (1990) and taking into account the general principles outlined by the European Commission, in authors' opinion, for a tax system to be effective, it should be based on five principles: consistency, adequacy, simplicity, transparent, and easy to manage. The principle should prevail over all as equity.

From research conducted, it can be said that the principle of equity should be corroborated by three features: coherence, adequacy, transparency, and facilitation. A coherent tax system implies the existence of clear, logically structured and without gates of interpretation. An appropriate fiscal supposed to generate sufficient tax revenue for the state government in order to fulfill its functions and to meet its public needs. A transparent tax system requires that all actors involved in the system of taxes and contributions have continuous and real-time access to all the information they need. Thus, the state can monitor the collection and taxpayers can see how public money is spent. An easy tax system supposed that the alignment mode of taxation should not be complicated or expensive for taxpayers or tax collectors. Rules should be known and simple and easy to make voluntary compliance. In an efficient tax system, tax collection cost should be small compared to the amount collected, and the state should carry out inspections at any tax in a fair and efficient.

In authors' view, a tax system that meets these characteristics can reduce administration and compliance costs, maximize tax collection process, and will lead to stimulating investment and to sustainable economic growth.

\section{Research Methods}

At the beginning of this work paper, it showed that the tax system was created for the beginning to fund the fulfillment of state functions, particularly meeting the needs of the public. Gradually, they were added to the

\footnotetext{
${ }^{1}$ Principle of tax equity is based on idea that all individuals should pay a fair share of taxes. Tax equity can be horizontal and vertical. Horizontal equity requires that any taxpayers who have similar financial circumstances should pay similar amounts in respect of taxes. This means that irrespective of the income tax rate for taxpayers is the same, therefore applies a tax system with a flat tax. Vertical equity requires that taxpayers with higher incomes pay at least the same rate of income tax for those who have lower incomes. Vertical equity implies classification of taxes as regressive, proportional, or progressive. Regressive tax implies taxpayers with lower income to allocate a larger share of income for paying taxes compared to those with higher incomes. Taxes on need, such as consumption taxes and excise taxes are regressive, because low-income people allocate a greater share of their income on these necessities.
} 
objective of economic and social.

In order to analyze the systems in the European Union, their classification was considered according to economic and social models that people have encountered in some countries.

Based on the literature (Aiginger \& Guger, 2006; Fingland \& Bailey, 2008; Paudyn, 2007) and taking into account the experience gained from its own research, it was observed that there is no agreement among the member states of the European Union on a common definition of the best tax system model. Instead, they emphasized different types of European socio-economic models, from three perspectives: accountability, regulation, and redistribution.

In terms of responsibility, it was found that in most states, there is a concern of society for the welfare of individuals to protect them from poverty and disease and to support them (more or less influenced) in case of unemployment and old. Currently, states are actively involved in economic and social life of its citizens, encouraging and actively promoting policies on education, health, and social protection (Retrieved from http://ec.europa.eu/eu2020/pdf/COMPLET\%20EN\%20BARROSO\%20\%20\%20007\%20-\%20Europe\%202020 $\% 20-\% 20$ EN\%20version.pdf). ${ }^{2}$ In terms of regulation, it was observed that in all states, labor relations are institutionalized and are based on social dialogue, labor law, and collective agreements. Business is regulated and formed by the social partners - corporate and subsidiary level. However, there are administrative regulations and collective economic product markets. Launching a business depends primarily on permits, authorizations, and legislative stability and less qualification owners or managers. Regarding redistribution, in most states, transfers, financial support, and social services are open to all groups. Differences in income redistribution are limited by financial transfers, property taxes, and inheritance.

Although at first glance, the European tax model appears to be uniform, Aiginger and Leoni (2009) have identified several versions of it. They made a distinction among: a Scandinavian model known as Nordic model; a model Continental known as the corporate or Rhineland model; a liberal model applied mainly in countries with less interference in the market and small transfers - the Anglo-Saxon model; Mediterranean model which includes countries of southern Europe; and a latter undertaking model-the Catching-up model that includes the new member states of the former socialist countries.

The models are distinguished in the first place by setting tax policy and its results are reflected in economic growth and the country's citizens outcomes (results reflected the increasing employment of labor that reduces unemployment and the welfare social level) and ultimately by geographical area.

In research conducted, quantitative data was used from Eurostat and from representative public institutions involved in financial and tax field in each country. For ease of addressing the topic, given the multitude of numeric, quantitative data source is passed to the bibliography at the end of the material.

\section{Research Results}

\section{Nordic Model}

Nordic model is found mainly in Sweden, Finland, Denmark, Netherlands, and Norway. This model is the largest in terms of number of countries that practice it. In this model, the focus is on redistribution and social benefits funding from taxes. This model is characterized by an active policy of labor market, which led to a

\footnotetext{
${ }^{2}$ According to Europe 2020 Strategy, a set of actions both at EU level and at the level of each member state of the European Union to increase the level of education, improved health, growth and development of the labor market, and poverty reduction was outlined.
} 
high rate of employment. In these countries, institutions working closely with the government and the unions are heavily involved in politics and social insurance. The tax system characteristic of the Nordic model is based on average and high levels of tax rates.

In terms of taxation, the analysis performed on countries covered by the Nordic model revealed the following characteristic features of this type of tax system.

Public fiscal revenue is based largely on income from direct taxes. Within the countries included in this tax model, the share of direct taxes in GDP is significantly higher in some cases, both the EU- $28^{3}$ average of 13.3\% in 2013 and the share of indirect taxes (in 2013, the share of indirect taxes was $31.8 \%$ in Denmark, 19.4\% in Norway, $18.5 \%$ in Sweden, and $16.9 \%$ in Finland). In Netherlands, in recent years under analysis, the weights of direct and indirect taxes seem to be at par. Applied corporate profit share is less than average compared to the average EU-28 23.1\% in 2014 (25\% in the Netherlands, 24.5\% in Denmark and Finland, 22\% in Sweden, and $20 \%$ share in Norway).

Income individuals are charged with the highest share of EU-28 area, where the average is $39.4 \%$ in 2014 (56.9\% in Sweden, 55.6\% in Denmark, 52\% in the Netherlands, $51.5 \%$ in Finland, and 39\% in Norway) and individual tax burden ${ }^{4}$ is above the average EU-28, from $45.06 \%$ in 2013 (48.7\% in the Netherlands, $47.6 \%$ in Sweden, $46.4 \%$ in Finland, $42.5 \%$ in Norway and $42.8 \%$ in Denmark). ${ }^{5}$ However, active labor market development and social protection, high levels of public expenditure, and social protection insurance make the Nordic welfare model found in the highest both from Europe and in other countries from other continents (in 2013, Holland is in the fourth place with $87.37 \%$, Norway in fifth place with $87.12 \%$, Sweden in sixth place with $87.08 \%$, Finland in the eighth place with $86.91 \%$, and Denmark in the ninth with $86.55 \%$ ). The implicit tax rate of the highest consumption rates was recorded in relation to the EU-28 countries, which is $21.6 \%$ (Denmark 30.5\%, Norway 29.3\%, Finland and Sweden 26.4\%, and the Netherlands 24.3\%). Tax rate has the highest share (Denmark 48.1\%, Sweden 44.2\%, Finland 44.1\%, Norway 42.2\%, and Netherlands 39.0\%) compared with the other countries included in the European models.

Tax policy focused on direct taxes, even if at first glance, it would lead to the idea that there is a high tax burden on individuals, combined with active welfare for citizens led to a low unemployment rate, well below the EU-28 by $10.8 \%$ in 2013 (3.5\% in Norway, which is in first place with the lowest unemployment rate among the analyzed countries, $6.7 \%$ in the Netherlands, $7 \%$ in Denmark, $8 \%$ in Sweden, and $8.2 \%$ in Finland). This is reflected in the level of employment. Thus, the countries within the Nordic model have the highest odds, as compared to the average EU-28 (68.3\% in 2013) and compared with the analyzed countries $(79.8 \%$ in Sweden, the highest in the European Union, $79.6 \%$ in Norway, $76.5 \%$ in the Netherlands, $75.6 \%$ in Denmark, and $73.3 \%$ in Finland).

In terms of the effect of this type of this tax system on economic growth, from the research conducted, it was noted that most of the countries included in the Nordic model showed an upward trend in terms of GDP (compared with 2012, in 2013, GDP registered an upward trend: $1.6 \%$ in Sweden, $0.6 \%$ in Norway, $0.4 \%$ in Denmark, and $-0.8 \%$ in Netherlands compared to $-1.2 \%$ ) and close to the EU-28. Fiscal stability pact (Retrieved from http://en.wikipedia.org/wiki/European_Fiscal_Compact\#cite_note-EC_ready-4) stipulates that the budget

\footnotetext{
3 Throughout the paper, it uses the abbreviation for the EU-28 for European Union with 28 countries.

${ }^{4}$ Individual tax burden was determined according to formula: individual tax burden $=\frac{\text { tax levy paid by individual }}{\text { gross income of the individual }} \times 100$

${ }^{5}$ Calculations are based on data from the country shown in Taxation trends in the European Union Eurostat by European Commission in 2014.
} 
is balanced when the budget deficit is within 3\% of GDP (in 2013, the EU-28 was 3.3\%). From this point of view, in 2013, the countries within the Nordic Model rank very good. In 2013, Norway recorded a surplus of $11.1 \%$ (it should be noted that throughout the period from 2006 to 2013, Norway has recorded a substantial surplus) and is the only country that has managed such a performance. The rest of the countries of Nordic Model record deficit but below 3\%, respectively: $-0.8 \%$ in Denmark $-1.1 \%$ in Sweden $-2.1 \%$ in Finland and $-2.5 \%$ in the Netherlands.

\section{Continental Model}

The continental model is found in Austria, Belgium, France, and Germany. In this model, employment and wages are the basis of social transfers. The social partners play an important role in labor relations and wage bargaining is centralized. In these countries, redistribution of public funds for social costs is not a priority.

In terms of taxation, the analysis performed on countries covered by the Continental model revealed the following characteristic features of this type of tax system.

Government fiscal revenue is based on both income from indirect taxation and direct taxation, slightly different proportions. Thus, in countries such as Austria and France, the share of indirect taxes in GDP is 1-2 percentage points higher than direct taxes. Compared with the average EU-28, the share of indirect taxes in GDP is $13.4 \%$, in the countries included in the continental model the share is higher by 1-3 percentage points. At first glance, people would believe that this model puts more emphasis on fiscal indirect taxation, but by analyzing the rates applied on consumption, it can be noted that, compared to other European tax systems here authors find the lowest rates. Therefore, the high share of indirect taxes in GDP and the large share of income tax in total revenue are not due to quotas. Conversely, lower rates of indirect taxation associated with active fiscal policy based on objectives related to the labor market, insurance, and social protection and facilities for business development led to increased tax revenue in total revenue (in 2013, the share of tax revenues in total budget revenues was $91 \%$ in Belgium, $90.3 \%$ in Austria, 90.2\% in France, and $89.7 \%$ in Germany). This has made the continental tax system to be the most effective in terms of participation of income taxes to the formation of total budget revenue.

Within the continental model countries, people have met the highest implicit tax personal income, compared to other European tax models (in 2013, 42.9\% in Belgium, 41.6\% in Austria, 40\% in France, and $37.8 \%$ in Germany). This is reflected also in the individual tax burden, which has the highest rate compared to the average EU-28 (45.06\%) and other European tax models taken into consideration (in 2013, 60.25\% in Belgium, 56.61\% in France, 55.77\% in Austria. Only Germany recorded a lower tax burden of 52.99\%). Research conducted noted that although implicit tax rate of labor is the largest, individual tax burden (compared to EU-28 countries and other European tax models), in terms of social welfare countries included in the Continental model is located in the top 20 countries (compared to all countries). Thus, in 2013 Austria was in 11 th place with a score of $85.11 \%$ welfare index, Germany ranked 12 th with $84.61 \%$, Belgium in 17 th place with $82.63 \%$, and France is at 20th place with $81.11 \%$. This is due to active labor market policy (stability and flexibility) and social protection (best interests of their own citizens).

From the research conducted, it was observed that the countries included in the continental model, health and social policy encourages population capable, but unemployed to find jobs by rethinking the social assistance system. So, individuals are interested in finding a job due to the reduction amount/period of 
unemployment (as initially promoted in Germany). On the other hand, labor market policy focuses primarily on job stability and flexibility, then it's the same company. Although it is known as European citizens' right to work in any country from Europe, yet, the countries included in the continental model are more reluctant when it comes to foreign labor, preferring its own citizens. This explains how the countries included in the continental model, at the 2013 level, the unemployment rate is the lowest rate of the average EU-28 (10.8\%) and other European tax models, respective $4.9 \%$ in Austria, 5.3\% in Germany, and $8.4 \%$ in Belgium. Only in France, unemployment has risen sharply in recent years, reaching $10.3 \%$ in 2013 . Currently, in order to overcome this situation, France launched an active labor market policy by promoting a system of subsidized jobs for young people and job flexibility.

In terms of economic growth, it can be seen how, in recent years, the countries within continental model recorded a steady increase in small steps GDP (in 2013, 0.4\% in Germany, 0.3\% in Austria, $0.2 \%$ in Belgium, and $0.2 \%$ in France). This is reflected in the budget deficit in 2013 which falls under the fiscal stability pact. Thus, Austria (-1.5\%), Belgium (- .2.6\%), and Germany (0\%) are below the $3 \%$ of GDP deficit. While France has a deficit of $-4.3 \%$ of GDP, there is a feeling of the effects of high unemployment and high costs of social assistance and protection which reflects an economy still in trouble.

\section{Anglo-Saxon Model}

The Anglo-Saxon tax model is found in Ireland and United Kingdom (UK). This model is characterized by a passive policy on labor market and social protection. In these countries, labor is not regulated, social transfers are smaller than other models, decentralized labor relations and wage bargaining takes place at the level of the employer.

In terms of taxation, the analysis performed on countries covered by the Anglo-Saxon model revealed the following characteristic features of this type of tax system.

In both countries, the participation of direct taxes to GDP is higher than that of indirect taxes $(13.2 \%$ in Ireland vs. $11.6 \%$, the UK $14.9 \%$ vs. $13.5 \%$ ). This was noted in most of the period under analysis.

Analyzing how to place direct taxes on individuals and businesses, it was seen that in countries included in the Anglo-Saxon model, the highest levels of corporate tax on companies are found. Tax rates on individual's income are high but are combined with a reduced system of mandatory social contributions. However, analyzing default rates of labor taxation, it found that they are among the lowest compared to the average EU-28 (35.36\%), so in 2013 the Irish rate was $28.9 \%$ and the UK is $25 \%$. This, together with the individual tax burden, which is the lowest compared (30.96\% in Ireland and the UK $36.35 \%$ in 2013) with the average EU-28 $(45.06 \%)$ as with the other countries taken into consideration and, taking into account the low share of social security contributions in GDP binding, it led to conclude that the large share of direct taxes in GDP is due to a very well developed system of collecting tax liabilities and the existence of a high degree of compliance tax. This is closely linked to the level of welfare. From this point of view, the UK ranks 13th place with $84.56 \%$ and Ireland ranks 15 th place with $84.05 \%$. When the welfare level is higher, also the level of tax compliance is higher.

From the point of view of economic growth during the period under review, it was noted that it records an upward trend, but oscillating. The UK recovers from the economic crisis, but GDP growth ranges from $1.7 \%$ in 2010 to $0.3 \%$ in 2012 and $1.7 \%$ in 2013; while Ireland recorded GDP growth of $2.2 \%$ in 2011 and then gradually decreased to $-0.3 \%$ in 2013 . 
Regarding the budget deficit, it was observed that Ireland and the UK have been hit hardest by the economic crisis and budget revenues could not face to support spending. Thus, in 2010, Ireland recorded the largest deficit (-30.6\% of GDP) compared to EU-28 countries. Immediately afterward, Ireland (following the example of other countries) asked financial assistance from international financial institutions (assistance program ended in late 2013). It followed a period of fiscal reform, in particular by increasing tax rates and an economic reform by rethinking economic development goals and reviewing/reduce spending. ${ }^{6}$ At the end of 2013, Ireland reached a deficit of $-7.2 \%$ of GDP, still below the threshold of the fiscal stability pact, but much better compared to the previous situation.

Regarding the UK, the budget deficit-to-GDP recorded high values above the average EU-28, especially during the economic crisis (from -11.4\% to -5.8\% in 2009 to 2013). Rapid decrease of the deficit was the result of a policy of stimulating productive investment (as a result of Fund Loan Scheme developed and applied by the Bank of England in cooperation with the Ministry of Finance to improve credit conditions by reducing borrowing costs development companies) (Retrieved from http://www.iem.ro/ro/publicatii/piaa-internaional/ economia-rilor-lumii/576-marea-britanie-cretere-economic-slab-in-2012-2013-relansare-moderat-in-2014).

\section{Mediterranean Model}

The Mediterranean tax model is encountered in Greece, Italy, Portugal, and Spain. In this model, the focus is on indirect taxation. These countries are heavily affected by the economic crisis and face a high level of public debt and budget deficit. In these countries, expenditure on social protection and security are very high, employment rate is almost at par with the unemployment rate (which is the highest compared to other countries taken into consideration), and representatives of trade unions and employers are active in negotiating wages and working conditions.

In terms of taxation, the analysis performed on countries covered by the Mediterranean model revealed the following characteristic features of this type of tax system.

Public fiscal revenue is based mostly on income from indirect taxation. The share of indirect taxes in GDP outperforms the share of direct taxes, throughout the period under review (in 2013, Greece, $12.8 \%$ vs. 9.8\%, in Portugal, $13.6 \%$ vs. $11.8 \%$, in Spain $11 \%$ vs. $10.3 \%$; Italy shares are at par). However, the implicit tax rate of consumption is lower than that seen in other European tax models (in 2013, 13.9\% in Spain, 16.1\% in Greece, $17.6 \%$ in Italy; In Portugal, the implicit tax rate average consumption is EU-28). Therefore, the higher share of indirect taxes in GDP compared to the share of direct taxes occurs due to low levels of employment, contributing less to the formation of budget revenues.

The level of taxation of employed labor force is below the EU-28 (39.4\%), with the exception of Italy. In 2013, the implicit tax rate on labor force was $43 \%$ in Italy, $38.2 \%$ in Greece, $33.7 \%$ in Spain, and $25.6 \%$ in Portugal. This is reflected in the individual tax burden which in the country in this tax model is close to the average EU-28 (45.6\%), respectively, for the year 2013, 42.2\% in Portugal, $44.45 \%$ in Spain, and $45.98 \%$ in Greece. The exception is again Italy, where in 2013 , the individual tax burden is $52.2 \%$ above the average EU-28. In case of Italy, it is clearly observed as the high implicit tax rate of labor attracts a large individual tax burden. It seems that among the countries contained in Mediterranean model, Italy was the most shaken from the point of view of the economic crisis. Not found viable solutions for growth and then, from 2011 they increased the income tax rate for individuals.

\footnotetext{
${ }^{6}$ Based on data from Eurostat.
} 
The high degree of debt of countries included in the Mediterranean model, reflected in the gross government debt to GDP (in 2013, recorded the highest share in the EU-28, 175.1\% in Greece, $132.6 \%$ in Italy, $129 \%$ in Portugal, and $93.9 \%$ in Spain) led to a reduction in public spending on health and welfare and to a highest tax burden of individuals. Blockage banking system, reducing the cost of investments, and reorganization of the payroll tax and taxation system increased the unemployment rate. Such countries included in The Mediterranean model have the highest unemployment rates in the EU-28 (in 2013, 27.5\% in Greece, $26.1 \%$ in Spain, $16.4 \%$ in Portugal, and $12.2 \%$ in Italy). This led to a reduction in social welfare in these countries. Thus, in 2013, in terms of the wealth index, Spain ranked 21st place with $80.77 \%$, Portugal is at 22nd place with $80.49 \%$, Italy is at 29th place with $76.93 \%$, and Greece in 35 th place with $73.43 \%$.

From the point of view of economic growth, it can be said that countries covered by the Mediterranean model were most affected by the economic crisis. It seems that there is still a total lack of economic reforms combined with distrust of population within government policy promoted by the public administration. From the analysis performed, it appears that these countries fail to recover from the economic point of view, although receiving financial assistance from international organizations. Thus, GDP growth is still negative (in 2013, $-3.9 \%$ in Greece, $-1.9 \%$ in Italy, $-1.4 \%$ in Portugal, and $-1.2 \%$ in Spain), and the budget deficit is still below the limit of fiscal stability pact (in 2013, $-12.7 \%$ in Greece, $-7.1 \%$ in Spain, $-4.9 \%$ in Portugal, and $-3 \%$ in Italy).

\section{Catching-up Model}

The catching-up model is found in the new member states of the European Union. In this model, it finds Bulgaria, Czech Republic, Poland, and Romania (Mosteanu, 2011). Countries that are part of this model apply a policy to support business development through a low corporate tax rates and tax breaks on start-up and business development and a policy of reorientation of labor force to private sector by granting tax incentives in this regard.

In terms of taxation, the analysis performed on countries covered by the catching-up model revealed the following characteristic features of this type of tax system.

In terms of participation in tax revenues in GDP during the period under review, it was observed that the level is lowest compared to countries from other tax models and to average EU-28 (39.08\%) and for 2013 it was $35.3 \%$ in the Czech Republic, 31.8\% in Poland, 28.1.\% in Bulgaria, and 27.5\% in Romania.

Catching-up tax model is based mainly on indirect taxation by applying high rates of taxation. This is one of the reasons why the share of revenues from indirect taxes in GDP is almost double the revenue from direct taxes.

Income tax rates are the lowest applied in EU-28 and among the analyzed countries $(10 \%$ in Bulgaria, $16 \%$ in Romania, 19\% in the Czech Republic and Poland). This contributed to business growth and attracted new foreign investment. Likewise, the labor rates applied are the lowest charged in the European area: 10\% in Bulgaria, 16\% in Romania, 22\% in the Czech Republic, and 32\% in Poland. This is reflected in the reduced individual tax burden (close to the average EU-28 by $45.06 \%$ ): $37.56 \%$ in Bulgaria, $44.43 \%$ in Poland, $46.43 \%$ Czech Republic, and 49.66\% in Romania.

Weakness of taxation in these countries is the lack of legislative stability and high levels of tax evasion. In addition, these add exchange rate instability.

Most countries of the European area and countries included in the catching-up model have been affected by unemployment, especially following the implementation of a policy to reduce public spending by 
restructuring and reorganizing their public institutional units. The bulk of employment in the public sector was forced to shift to the private sector. Even if tax reforms came with a package of tax breaks to encourage employment available, it appears that further Bulgaria (13\%) and Poland (10.3\%) experiencing high levels of unemployment compared to the EU average -28 (10.8\%).

Although the personal income tax is one of the lowest in the EU-28 area, low wages level (compared to other EU member states) and the high rate of taxation on consumption and public utilities price increase (more faster than wage growth) have made the welfare index to be the lowest among the countries of the world. The Czech Republic ranks 23 with 80.41\%, Poland ranks 24th place with $77.44 \%$, Bulgaria ranks 44th with $70.24 \%$, and Romania ranks 51 st place with $67.72 \%$ (the lowest place among the countries analyzed).

In terms of growth, it appears that fiscal easing policy, active labor market policy, regional economic development policy, and the access to financial and technical assistance from international financial institutions led to a reduction of the budget deficit, extending to its matching contained within the stability pact fiscal (in 2013, $-1.5 \%$ in Bulgaria and the Czech Republic, $-2.3 \%$ in Romania). The exception is Poland, where the share of budget deficit to GDP is still below the limit, i.e. $-4.3 \%$ in Poland in 2013, but compared to $2009(-7.5 \%)$ it decreased significantly. This is seen in the evolution of GDP, which in recent years recorded positive growth. In 2013, GDP growth was 3.5\% in Romania (the highest increase in Europe), $1.6 \%$ in Poland, and $0.9 \%$ in Bulgaria. Czech Republic still needs to recover, recording negative growth of $-0.9 \%$ in 2013. As regards public debt to GDP, the countries included in catching-up model are the best, with values below $60 \%$.

\section{Conclusions}

Through this work paper, it presents theoretical elements on tax systems and analyzes the models of tax system of member states of the EU. In research conducted, following indicators were used: indirect taxes, direct and implicit tax rates of consumption and labor, individual tax burden, unemployment, welfare index, economic growth, deficit and debt, during the period from 2006 to 2013 (as can be seen in Figure 1, 2, 3, 4, and 5).

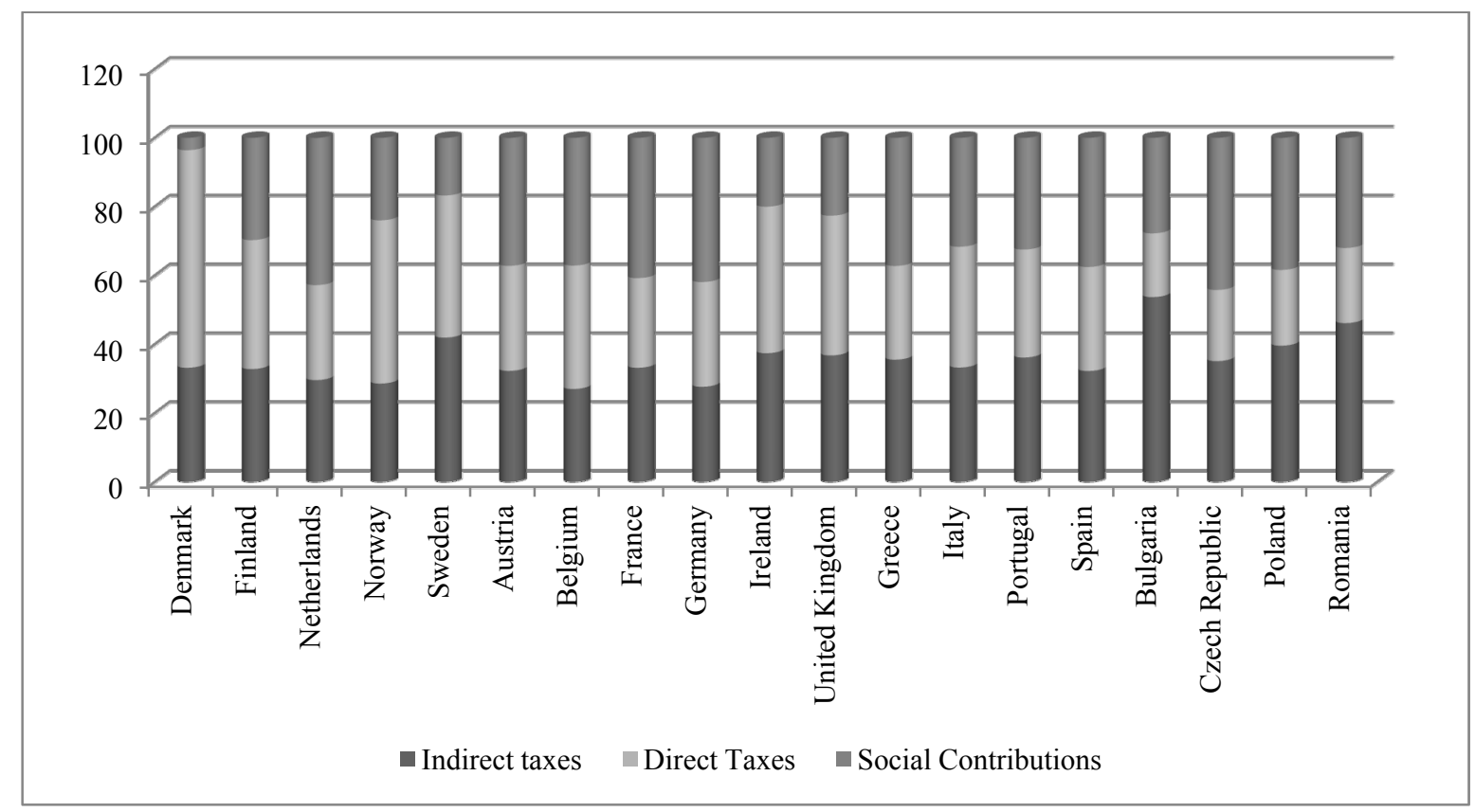

Figure 1. The structure of tax revenue in 2013. Source: Retrieved from http://ec.europa.eu/taxation_customs/taxation/. 


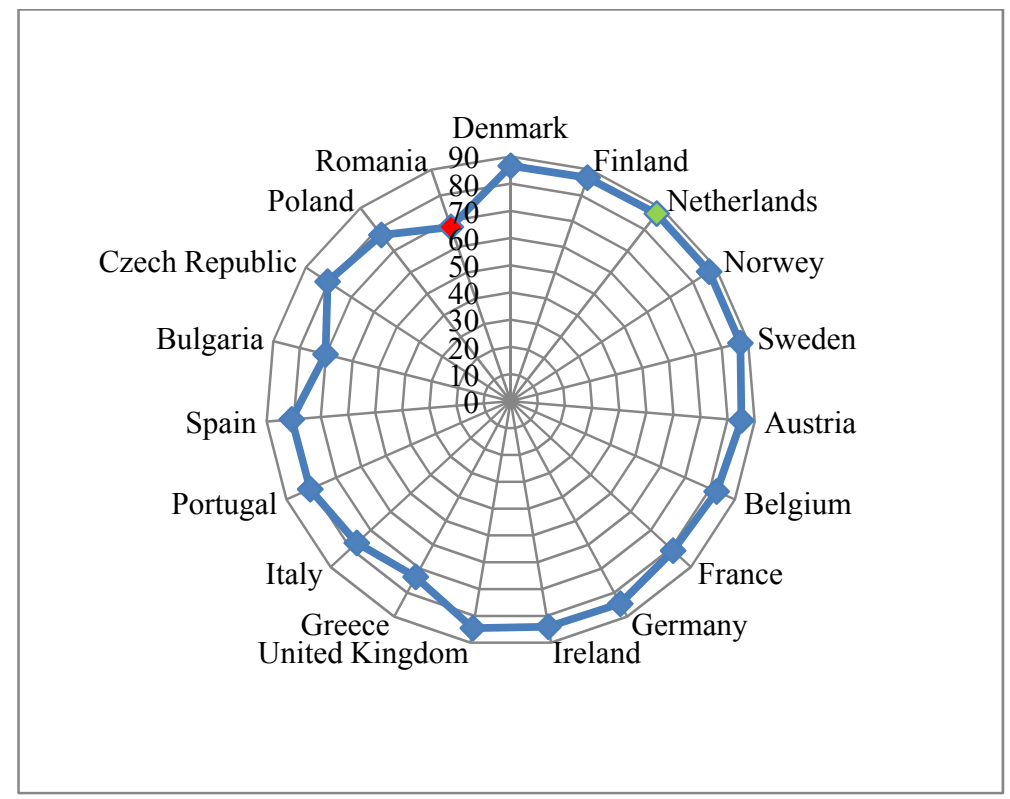

Figure 2. Welfare index in 2014. Source: Social Progress Index.

Based on European tax models identified by economists Aiginger and Guger (2006) and analyzing economic indicators presented above, it can be concluded that it distinguishes the following characteristic features for each model European tax basis.

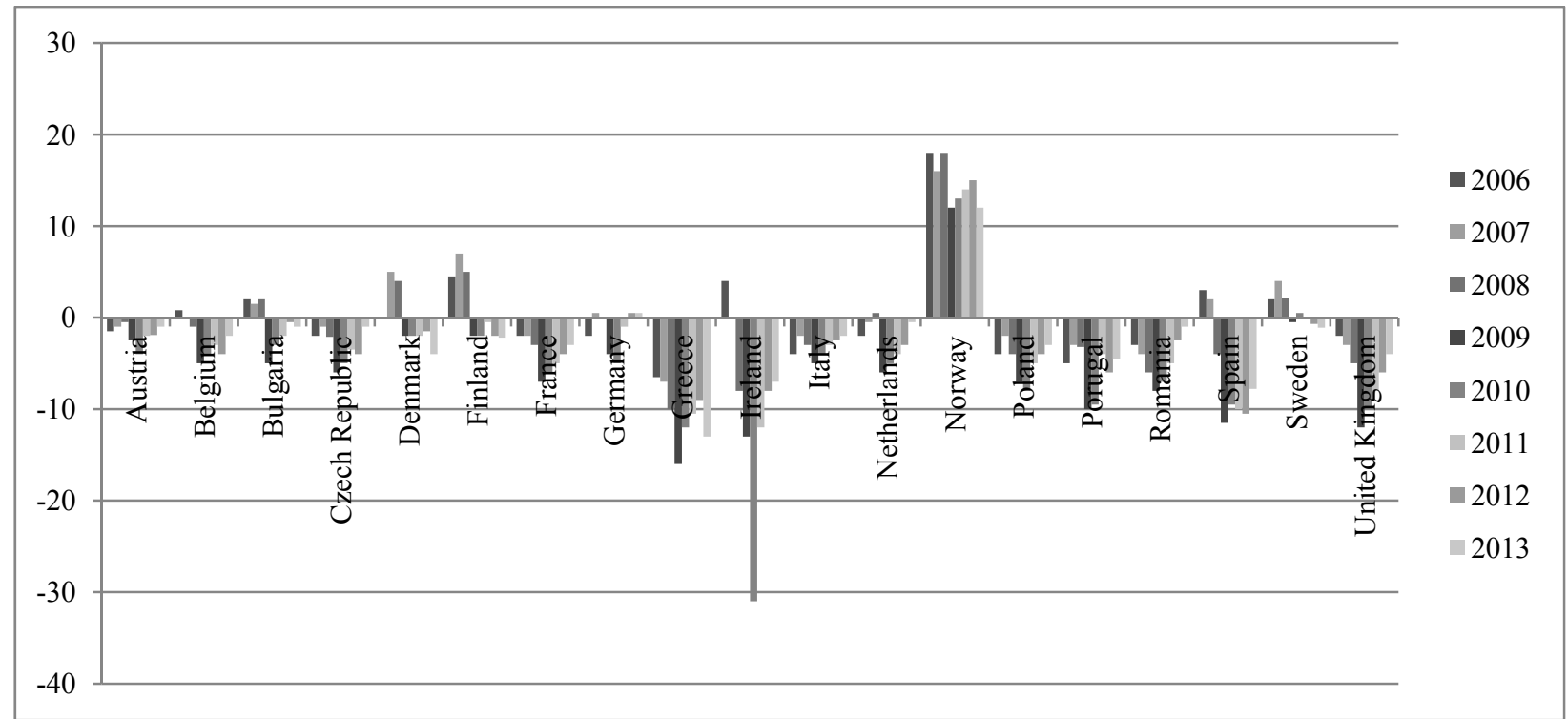

Figure 3. Economic growth of member states of the European Union during the period from 2006 to 2013. Source Retrieved from http://ec.europa.eu/taxation_customs/taxation/.

In the Nordic model, direct taxes mainly participates in the formation of public revenue, the welfare index is the highest in Europe, the employment level is the highest, economic growth has an upward trend, while the share of the budget deficit and public debt to GDP is within the fiscal stability pact. The Nordic model focuses on redistribution and social benefits are financed from tax revenues. Within this model, the highest rate of tax collection can be found. From the point of view of welfare index, the tax model is most effective. 


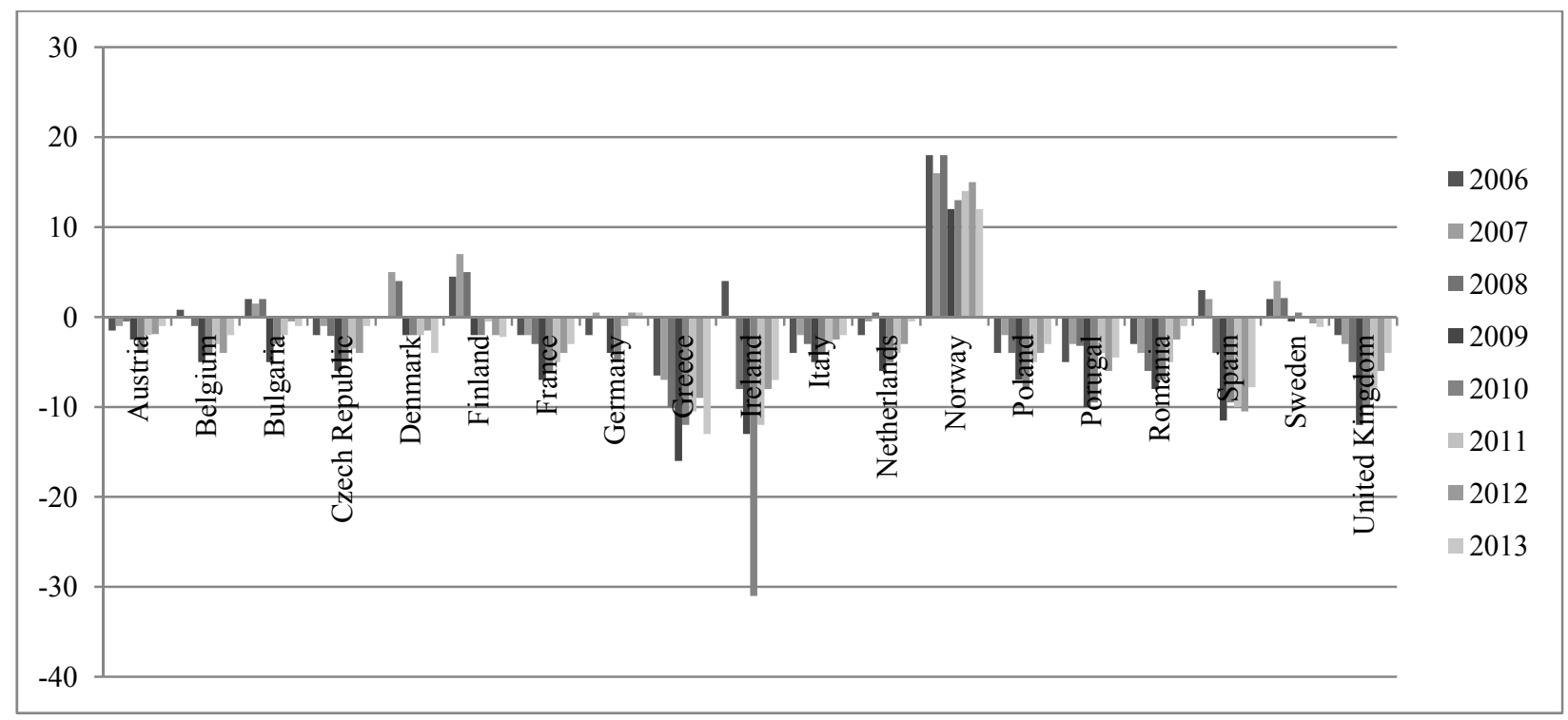

Figure 4. Share of deficit in GDP within Member States of the European Union, during the period 2006-2013. Source Retrieved from http://ec.europa.eu/taxation_customs/taxation/.

In the continental model, direct and indirect taxes almost equally participate in the formation of public revenues, implicit tax rate on incomes of individuals and individual tax burden are the highest rate recorded, unemployment is lowest and social welfare index puts this tax model on second place between European tax models. Within the continental model, the emphasis is more on employment and, therefore the greatest share of revenue to the state budget is given by contributions. GDP has an upward trend, the share of budgetary deficit in GDP is within the fiscal stability pact, but the level of public debt is still very high, exceeding the $60 \%$ limit.

In the Anglo-Saxon model, participation of direct taxes in GDP is higher, tax rates on incomes of individuals are higher, but social contribution rates are lower which leads to the lowest implicit tax rate on labor that can be observed in the individual tax burden, which is also the lowest. The Anglo-Saxon model emphasizes on individual responsibility, therefore labor is not regulated. In this model, the lowest collection rate of social contributions could be found. From the point of view of economic growth and the budget deficit, the countries in the Anglo-Saxon model were most affected and recorded weak growth and budgetary deficit and public debt to GDP well below showed in fiscal stability pact.

In the Mediterranean model, indirect taxes largely participate in the formation of tax revenue, the labor tax is medium, the individual tax burden is high, the highest rate of unemployment is recorded, indebtedness is the highest, economic growth still has values below zero, and the budget deficit is below the permissible threshold of fiscal stability pact. It can be said that countries that are part of this model have been most affected by the economic crisis and still there is a total lack of economic reforms combined with public distrust of government policy promoted by the government. It seems that these countries fail to recover from the economic point of view, although receiving financial assistance from international organizations.

Within the catching-up model, tax revenue participation in GDP is lower than that in other countries taken into consideration, tax revenues consist mostly of indirect taxes, and taxation occurs at the lowest rate, unemployment rate approaching EU-28 average. The countries included in catching-up model are observed a low level of wages and social welfare index also lower (Bulgaria and Romania are on the last two places between EU countries). Due to technical and financial support provided by international financial institutions 
and a policy which supports small and medium enterprises, practicing more favorable tax rates for business, countries included in catching-up model recorded positive growth, budget deficit, and public debt in the threshold limits set for fiscal stability pact. However, it should be noted that countries within the catching-up model experience instability legislative system with taxation and combate low level of avoiding tax evasion.

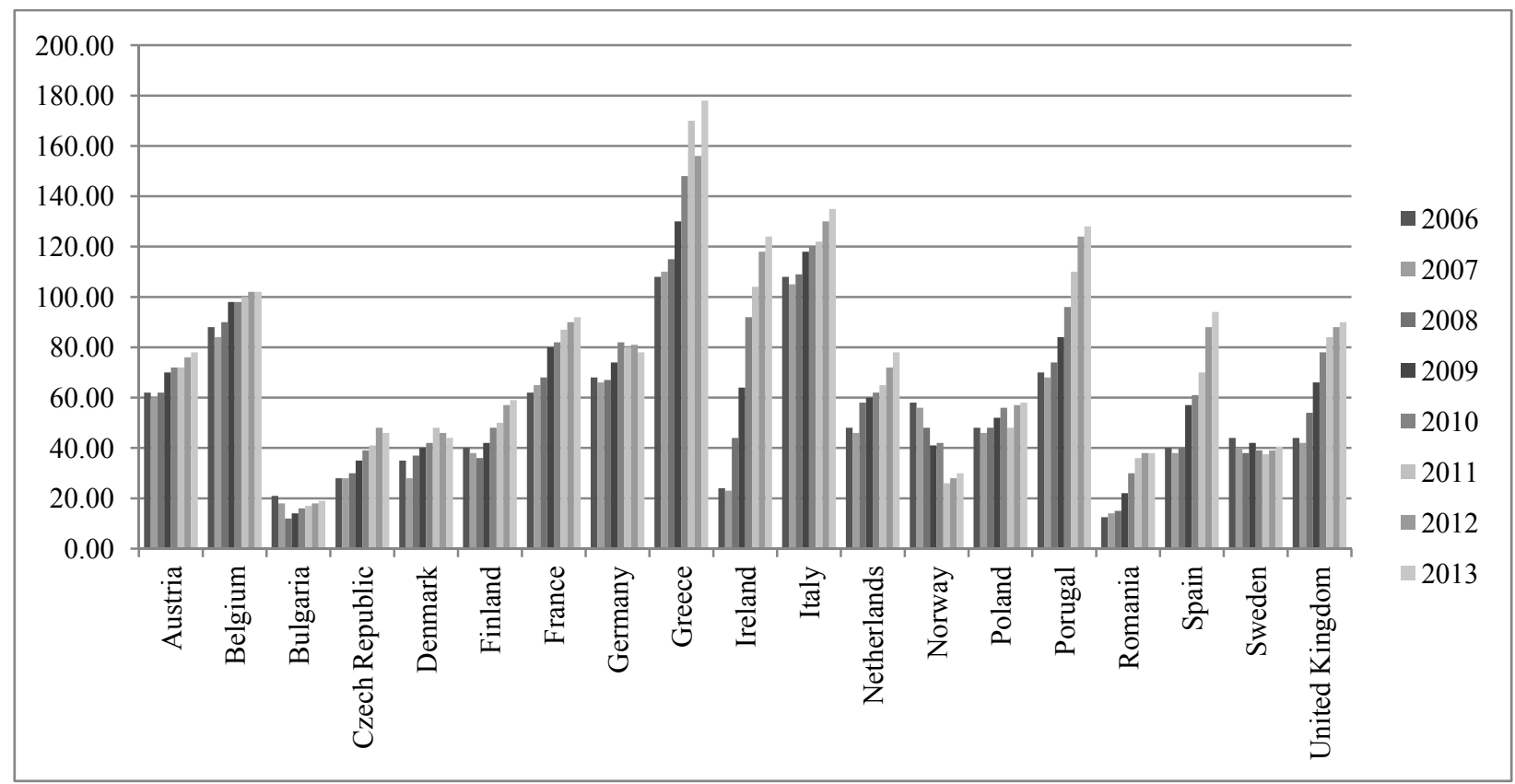

Figure 5. Share of public debt in GDP within member states of the European Union during the period from 2006 to 2013. Source Retrieved from http://ec.europa.eu/taxation_customs/taxation/.

In the research, it has concluded that, as long as the rules of the EU, member states are free to choose their own tax system which they consider nearest their needs and preferences. However, the EU will take any action to comply with taxation principles of subsidiary and proportionality. EU intervenes only where member states cannot come up with effective solutions in the development of a fair tax system and optimally.

\section{References}

Aiginger, K., \& Guger, A. (2006). The European socio-economic model-differences to the USA and changes over time. Retrieved from http://www.forschungsnetzwerk.at/downloadpub/WP_2005_266.pdf

Aiginger, K., \& Leoni, T. (2009). Typologies of social models in Europe. Retrieved from http://www.socialpolitik.ovgu.de/sozialpolitik_media/papers/Aiginger_Karl_uid563_pid502.pdf

European Commission. (2010). Europe 2020: An European strategy for smart sustainable and inclusive growth. Retrieved from http://ec.europa.eu/eu2020/pdf/COMPLET\%20EN\%20BARROSO\%20\%20\%20007\%20-\%20Europe\%202020\%20-\%20EN $\% 20$ version.pdf

European Commission. (2014). General tax principles. Retrieved from http://ec.europa.eu/taxation_customs/resources/documents/taxation/company_tax/common_tax_base/cctbwp1finalrev1_en.pd $\mathrm{f}$

European Commission. (2014). Taxation trends in the European Union. Retrieved from http://ec.europa.eu/taxation_customs/taxation/

European Commission. (n.d.) Fiscal stability treaty. $\quad$ Retrieved from http://en.wikipedia.org/wiki/European_Fiscal_Compact\#cite_note-EC_ready-4

Fingland, L., \& Bailey, S. (2008). The EU's stability and growth pact: It's credibility and sustainability. Retrieved from http://papers.ssrn.com/sol3/papers.cfm?abstract_id=1158786 
Mosteanu, N. R. (2011). Tehnici fiscale-Fiscal techniques (Editura Universitara, București).

Musgrave, R. A. (1990). Horizontal equity, once more. National Tax Journal, 43(2), 113-122.

Paudyn, B. (2007). Regulating European monetary relations through risk and uncertainty: Governance and the asymmetric application of the stability and growth pact. Proceedings from the Annual Convention of the International Studies Association.

Simona, P. (2014). Marea Britanie-creştere economică slabă în 2012-2013. Retrieved from http://www.iem.ro/ro/publicatii/piaa-internaional/economia-rilor-lumii/576-marea-britanie-cretere-economic-slab-in-2012-20 13-relansare-moderat-in-2014

Smith, A. (1776a). An inquiry into the nature and causes of the wealth of nations. London: Methuen \& Co., Ltd..

Smith, A. (1776b). The wealth of nations. Retrieved from http://political-economy.com/wealth-of-nations-adam-smith/ 